\title{
Factors that Influence Audit Delay in the Trade, Service, and Investment Sector that Listed on Indonesian Stock Exchange
}

\author{
Rohana Dita Safitri ${ }^{1 *}$, Ni Nyoman Alit Triani ${ }^{2}$ \\ 1,2 Accounting Department, State University of Surabaya, \\ Jl. Lidah Wetan, Surabaya 60213, Indonesia \\ *Corresponding author; Email: ${ }^{*}$ rohana.17080694059@mhs.unesa.ac.id, 2nyomanalit@unesa.ac.id
}

\begin{abstract}
The purpose of this study is to provide empirical evidence of the effect of company size, audit opinion, the complexity of company operations, audit tenure, and KAP specialization on audit delay. The sampling method used was purposive sampling on companies in the trade, service, and investment sectors for the period 2013-2018 and produced 447 data. The research data were analyzed using multiple linear regression analysis. The results of data analysis show that company size and audit opinion affect audit delay meanwhile, the complexity of company operations, audit tenure, KAP specialization does not affect audit delay. The implication of this research can be used by users of financial statements to review the company's operational effectiveness or consider whether to continue investing in the company or not. The implications from the company side are related to the disclosure of information and the accuracy of the submission of financial reports.
\end{abstract}

Keywords: Firm size; audit opinion; company operation complexity; audit tenure; KAP specialization; audit delay.

\section{INTRODUCTION}

The length of time in the submission of financial statements is measured from the closing of the financial reporting year to the completion of the audit financial statements by an independent auditor called audit delay [12]. According to [13], audit delay is divided into three types, the first is initial lag, which is calculated based on the distance between the end date of the fiscal year and the date the financial statements are received by the capital market. Both auditor's signature lag, calculated based on the distance between the end date of the fiscal year and the date recorded in the independent auditor's report. Finally, the total lag is calculated based on the distance between the end of the fiscal year and the date on which the annual financial statements are published by the capital market. Auditor's signature lag is a type of audit delay that will be used in this study.

Financial Services Authority Regulation [33] No. 44 / POJK.04 / 2016 concerning the financial statements by public companies Article 7 has stated that the submission of annual reports is a maximum of four (4) months after the financial year is closed. Sanctions for companies that are late in reporting their yearly reports are regulated in the decision of the board of directors of PT. Bursa Efek Jakarta Number: Kep-307 / BEI / 07-2004 concerning Regulation Number $1 \mathrm{H}$ concerning Sanctions which states that there are three warnings as well as fines for the delay and the heaviest sanctions are imposed suspension.

IDX data in 2018 states that Indonesia is the only country that has the largest return on investment in the world, reaching $3.17 \%$ and a total market capitalization of 6,400 trillion [34]. According to signal theory, this is good news for investors. Timely submission of financial reports to external parties is very important to maintain the relevance of information in financial reports and maintain public trust. For investors, timely submission of financial reports will reduce uncertainty in investment decision-making and the dissemination of asymmetric information among investors in the capital market. A shorter timeframe for disclosure of audited financial statements is important for influencing the decision-making process by users of information [19].

The chart above noted that 52 issuers experienced audit delays in 2014 [4], then decreased in 2015 to 18 issuers [5], and again reduced in 2016 to 17 issuers [6]. In 2017 there were only 10 issuers that experienced audit delays [7] and this number was stagnant until 2018 [8]. There was a drastic increase in 2019 to 42 issuers experiencing audit delays [9].

Several factors can cause delays in submitting the financial statements. These factors, namely company size, auditor opinion, the complexity of 


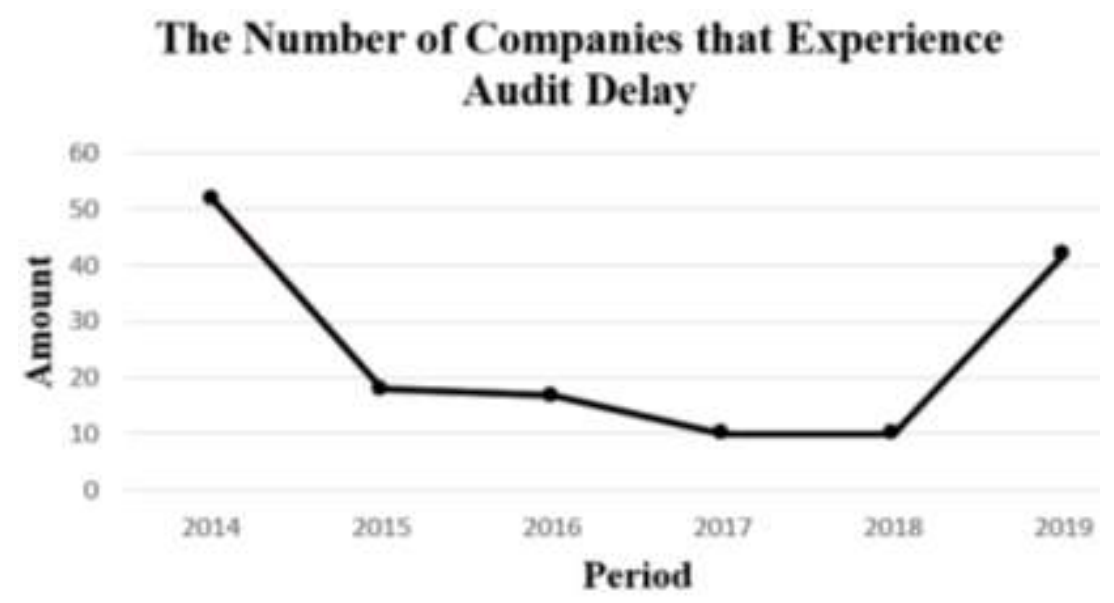

Source: IDX (compiled by the author)

Figure 1. Issuers experiencing audit delay for the 2015 -2019 period

company operations, audit tenure, and KAP specialization. The results of previous research by [25] and [26] state that there is a negative influence between company size and audit delay. In contrast, the results of [2] and [39] found no influence between company size and audit delay. This is because companies listed on the Indonesian stock exchange are monitored by investors, capital supervisors, the government, and the public so that companies large and small face the same pressure [39].

The findings [11] and [28] audit delay is affected by the complexity of the operating company in a positive. This is because high accounting complexity is linear with audit complexity and risk so that auditors need a longer time to perform the audit process. The other hand [1] and [35] found the complexity of company operations does not affect audit delay. This can be anticipated by careful preparation of the audit plan, thereby reducing the audit time budget.

The previous year's auditor's options can affect the audit delay. [17] and [20] have proven that companies that get qualified opinions have longer audit delays than companies that get unqualified opinions. However, according to [39] the auditor's opinion does not affect audit delay.

Findings by [10] and [37] state that it takes a longer time for short-term auditors to issue audit reports because extra time is needed with client operations. However, the findings [1] and [23] state that audit tenure does not affect audit delay. The short maximum tenure in Indonesia is considered insufficient for the auditor to have special knowledge related to the company being audited.

According to [14] and [18], the KAP specialization has a shorter audit delay. It is different from the findings [1] and [12] which state that KAP specialization does not affect audit delay. During the audit implementation period, KAP only became the overseeing agency, while the public accountant was the one conducting the audit. [24] explain that with the rotation of auditors, it is not easy for KAP to become experts and gain specialization status in a certain industry.

The results of previous studies indicate a significant research gap. This becomes the reference for researchers to re-test several variables and is based on the conditions of the company in Indonesia. This study examines the effect of firm size, auditor opinion, the complexity of company operations, audit tenure, and KAP specialization on audit delay. The selected sectors are the trade, services, and investment sectors that listed on the IDX for the period 2013 - 2018.

\section{Signaling Theory}

[36] in his research entitled JobMarket Signaling states that signaling theory involves two parties, namely internal parties such as managers who have a role as signaling parties and external parties such as investors as signal receivers. Management tries to provide credible and relevant information that can be used by investors. One type of statement released by a company that can signal outsiders, especially for investors, is an annual report. Annual reports contain accounting information, namely information related to the financial statements, and non-accounting information that is not related to the financial statements [41].

Accounting and non-accounting information contained in this annual report will be assessed by outsiders, whether the company has good or bad prospects in the future. If the information has a good judgment, investors will consider it good news and will respond to this by investing in the company. Conversely, if the information provided shows a bad 
judgment, investors will consider it bad news. This will affect the stock price as well as the behavior of investors who might withdraw their investment from the company.

\section{Lending Credibility Theory}

One of the functions of the audit is to increase the credibility of financial statements. Audited financial statements are one of the tools used by management to maintain stakeholder trust in management oversight [22]. Audited financial statements can increase stakeholder confidence in the information presented that the information is a fair representation. Companies that are timely in submitting audited financial statements reflect that the company has quality work and credibility in the information submitted [30].

\section{Audit Delay}

[27] defines audit delay as the time required for the auditor to complete his audit work, which is measured from the closing date of the financial year until the issuance of the audited financial statements. [12] also defines audit delay as the length of time in the submission of financial statements, measured from the closing of the financial reporting year to the completion of audited financial statements by an independent auditor. The longer the auditor completes the audit work, the longer the audit delay will be.

According to [13] the audit delay pattern is divided into three-time interval patterns which explain the existence of each delay which consists of: a. Preliminary lag is calculated based on the interval between the end date of the fiscal year and the date the financial statements are received by the capital market.

b. The auditor's signature lag is calculated based on the interval between the end date of the fiscal year and the date stated in the auditor's report.

c. The total lag is calculated based on the interval between the end of the fiscal year and the date on which the annual financial statements are published by the capital market.

\section{Hypothesis Development}

\section{The Effect of Company Size on Audit Delay}

According to [15], company size can be classified in various ways: total assets, sales, log size, stock market value, market capitalization, and others, all of which correlate. Larger companies tend to have an effective and efficient internal control system that makes it easier for auditors to audit a company [31]. It takes a larger number of samples and broader audit procedures for large companies [21]. Large companies generally have good internal controls in terms of budgeting for their cost accountability processes.

This raises some pressure for auditors to immediately submit reports on the results of their audits [25]. Timeliness in submitting financial statements is one way for large companies to maintain their image or corporate image in the eyes of the public [41]. Large companies tend to have external pressures such as maintaining the confidence of investors who make the financial statements to be published immediately so that the audit delay period is shorter [29]. Based on this explanation, the hypothesis is formulated as follows: H1: There is a significant effect between the company size and the audit delay

\section{The Effect of Auditor's Opinion on Audit Delay}

According to [40], one of the objectives of the auditor is to formulate an opinion on the financial statements based on the audit findings. The auditor's opinion is one of the signals for investors to determine the condition of the company. When the company gets a qualified opinion, management tries to postpone the publication of qualified opinion financial statements which is bad news for investors and parties with other interests [20]. Auditors are expected to expand their audit process when they discover or suspect irregularities and require more time.

This can be used as a defense against possible future litigation [25]. Audit opinion, which has the potential to provide bad news for the company, encourages auditors to resolve findings through negotiations or discussions with the parties involved [17]. Opinions other than unqualified encourage companies to change auditors and re-negotiate to maintain their image in the eyes of the public [29]. This makes the audit delay period even longer. Based on this explanation, the hypothesis is formulated as follows:

H2: There is a significant effect between the auditor's opinion and the audit delay

\section{The Effect of The Complexity of The Company's Operations on Audit Delay}

The complexity of company operations relates to the company units that are interrelated and work together to achieve company goals. The number of subsidiaries is one measuring tool to determine the complexity of operations. Companies with a significant number of subsidiaries will have a long audit delay [18]. This is due to the complexity inherent in 
auditing the company. The number of subsidiaries owned by the company reflects the company's broad operating units so that it takes longer to audit the financial statements [21]. High accounting complexity is linear with audit complexity and risk so that auditors need a longer time to carry out the audit process [1].

The more diverse and complex the company's operations are, the higher the potential for material errors and the more complex the audit work will be [28]. This makes the audit delay period even longer. Based on this explanation, the hypothesis is formulated as follows:

H3: There is a significant effect between the complexity of company operations and the audit delay

\section{The Effect of Audit Tenure on Audit Delay}

Audit tenure is the length of the work engagement period of a Public Accounting Firm (KAP), which is the same as a company providing the financial statements audit services [16]. Public accounting firms with short tenure have longer audit delays because they require more time to understand the client's operations and industry [37]. Initial audit engagements tend to be less efficient than arrangements in subsequent years. Audit delay will be shorter for a longer tenure. This is because auditors have become accustomed to business operations, internal control, and previous paperwork [29].

Auditors with a longer tenure can gather more client-specific knowledge so that they have a better understanding and shorten the audit process carried out [17]. Based on this explanation, the hypothesis is formulated as follows:

H4: There is a significant effect between audit tenure and the audit delay

\section{The Effect of KAP Specialization on Audit Delay}

Industry-specialized KAPs generally have more expertise and experience in detecting potential errors or fraud in their specialization [16]. Besides, $\mathrm{KAP}$ with industry specialization has more access to technology, physical facilities, personnel, industrial control systems, which results in high audit process efficiency and audit quality [11]. Auditors with industry specialties tend to have a specific understanding of a particular industry which causes them to have a more complex knowledge of the industry [1].

Industry specialization enables auditors to more precisely evaluate the potential risks faced by clients [17]. Auditors who are specialized in the industry need less time to understand the client's financial reporting system and to resolve complex accounting problems than non-specialist auditors [14]. Based on this explanation, the hypothesis is formulated as follows:

H5: There is a significant effect between KAP specialization and the audit delay

\section{RESEARCH METHOD}

\section{Population and Sample}

This study uses a quantitative approach with a population, namely all companies listed on the IDX for the 2013-2018 period. The sample in this study is the trade, service, and investment sectors. This sample was chosen because, during the observation period, the companies that experienced the most audit delays were that sector. The sample collection used purposive sampling. The total sample of companies that were listed during the observation period was 654 . However, the data was not fully available, so that 84 had to issue data. Furthermore, when testing was carried out there were 123 data that had to be outsourced and resulted in 447 final data.

\section{Definition of Operational and Measurement Variables}

\section{Dependent Variable}

[27] defines audit delay as the time required for the auditor to complete his audit work, which is measured from the closing date of the financial year until the issuance of the audited financial statements. This variable is calculated based on the interval between the end date of the fiscal year and the date stated in the auditor's report [38].

\section{Independent Variables}

The independent variables used in this study were the company size, auditor's opinion, the complexity of company operations, audit tenure, and KAP specialization. The measurements of each independent variable can be explained in the following sections.

According to [15], company size can be classified in various ways: total assets, sales, log size, stock market value, market capitalization, and others, all of which correlate. In this study, company size is measured by the natural logarithm of the company's total assets. The measurement of company size referred to a study by [25] and [30]. 
The statement of an opinion by the auditor can increase the stakeholders' confidence in the information presented that the information is a fair representation. In this study, the auditor's statement is measured by dummy variables, if the company gets an opinion other than unqualified is given a value of 1 , and if it gets an unqualified opinion it is given a value of 0 . The measurement of auditor's opinion referred to a study by [20] and [39].

The complexity of company operations relates to the company units that are interrelated and work together to achieve company goals. The number of subsidiaries is one of the measuring tools to determine the complexity of the company's operations. In this study, the complexity of the company's operations is calculated by the number of subsidiaries. The measurement of the complexity of company operations referred to a study by [1] and [12].

Audit tenure has a definition of the length of the tenure of a Public Accounting Firm (KAP) which is the same as a company in terms of providing the financial statements audit services. In this study, audit tenure is measured by a dummy variable, if the company was audited by the same auditor for three years it was given a value of 1 , and if the company was not audited by the same auditor for three years it was given a value of 0 . The measurement of audit tenure referred to a study by [10] and [20].

Industry specialized KAPs generally have more expertise and experience in detecting potential errors or fraud in their specialization. In this study, KAP specialization is measured by a dummy variable, if the company audited by a KAP that specializes in the trade, service, and investment sectors is given a value of 1 , and if the company is not audited by a KAP that specializes in the trade, service, and investment sectors, it will be given a value 0 . The measurement of KAP specialization referred to a study by [14] and [17].

This research data analysis using descriptive statistics, classical assumption test, and hypothesis testing. Multiple linear regression tests in the form of partial testing (T-test) and simultaneous testing (F test). The regression models in this study are:

$$
\begin{gathered}
A U D E=\alpha_{0}+\alpha_{1} S I Z E+\alpha_{2} O P N+\alpha_{3} S U B S I \\
+\alpha_{4} T N R E+\alpha_{5} K A P+\varepsilon
\end{gathered}
$$

Notes:

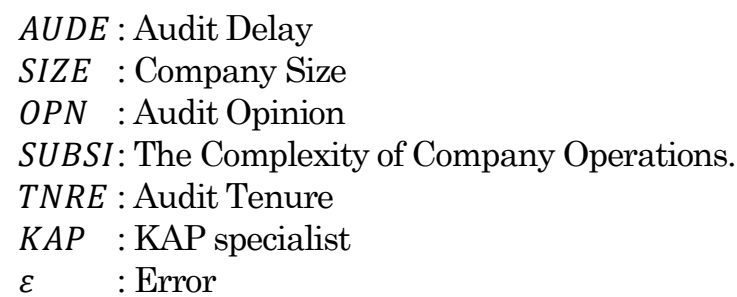

\section{RESULT AND DISCUSSION}

Table 1. Descriptive Statistics Test

\begin{tabular}{lcccc}
\hline & Min & Max & Mean & Std. Dev \\
\hline SIZE & 24,53 & 31,66 & 28,21 & 1,62 \\
OPN &, 00 & 1,00 &, 01 &, 01 \\
SUBSI &, 00 & 4,41 & 1,64 & 1,24 \\
TNRE &, 00 & 1,00 &, 99 &, 09 \\
KAP &, 00 & 1,00 &, 39 &, 49 \\
AUDE & 4,17 & 4,61 & 4,39 &, 08 \\
Valid N & 447 & & & \\
(listwise) & & & & \\
\hline
\end{tabular}

Source: processed by SPSS

Table 1 shows that the number of company data used in the study was 447 . The descriptive statistical results of the audit delay variable have a minimum value of 4.17 or 65 days, namely in the advertising, health, and wholesale sub-sectors. The maximum value of 4.61 or 100 days is in the tourism sub-sector with a mean value of 4.39 or 81 days and an std value deviation of 0.08 . The descriptive statistical results of the size variable have a minimum value of 24,53 or 45 billion, namely in the tourism sub-sector. The maximum value of 31,66 or 56 trillion is in the investment sub-sector with a mean value of 28,21 or 1 trillion and an std value deviation of 1,62 . The sub-sectors that received the most opinion apart from being unqualified were wholesale and tourism. The descriptive statistical results of the subsidiaries variable have a minimum value of 0 , namely the most in the wholesale subsector. The maximum value of 4,41 or 82 is in the health sub-sector with a mean value of 1,64 or 6 and an std value deviation of 1,24 . The sub-sector with the most tenures of more than 3 years is wholesale. The sub-sectors that were mostly audited by KAP specialists were advertising and tourism.

Table 2. Results of the coefficient of determination

\begin{tabular}{cccc}
\hline Model & $\mathrm{R}$ & R Square & Adjusted R Square \\
\hline 1 & 0,198 & 0,039 & 0,028 \\
\hline
\end{tabular}

Source: processed by SPSS

Table 2, the value of Adjusted R Square shows that the dependent variable can explain the independent variables by 0.028 or $3 \%$, and the remaining $97 \%$ is explained by variables other than in this study.

Table 3. F Test Results

\begin{tabular}{lcccc}
\hline \multicolumn{1}{c}{ Model } & Df & $\begin{array}{c}\text { Mean } \\
\text { square }\end{array}$ & F & Sig. \\
\hline Regression & 5 & 0.023 & 3,604 & 0.003 \\
Residual & 441 & 0.006 & & \\
Total & 446 & & & \\
\hline Source: processed by SPSS & & &
\end{tabular}


$\mathrm{F}$ test results table 3 shows that the $\mathrm{F}$ value is 3.604 with a significance of 0.003 . Because the significant value is less than 0.005 , it can be concluded that the regression model is simultaneously able to predict the audit delay variable.

Table 4. t-test results

\begin{tabular}{lllll}
\hline \multirow{5}{*}{ Model } & \multicolumn{2}{c}{$\begin{array}{c}\text { Unstandardized } \\
\text { Coefficients }\end{array}$} & \multirow{2}{*}{$\mathrm{t}$} & Sig. \\
\cline { 2 - 3 } & $\mathrm{B}$ & $\begin{array}{c}\text { Std. } \\
\text { Error }\end{array}$ & & \\
\hline (Constant) & 4,204 & 0.097 & 43,317 & \\
SIZE & -0.008 & 0.003 & $-2,327$ & $0.020^{*}$ \\
OPN & 0.141 & 0.069 & 2,336 & $0.020^{*}$ \\
SUBSI & 0.001 & 0.004 & 0.312 & 0,755 \\
TNRE & $-0,022$ & 0.043 & $-0,519$ & 0,604 \\
KAP & -0.010 & 0.008 & $-1,129$ & 0,259 \\
*Significant at 5\% level & & & \\
\hline
\end{tabular}

Source: processed by SPSS

Based on table 4, The test results show that company size (SIZE) can negatively affect the audit delay because it has a significance value of less than 0.05 with a coefficient value of -0.008 . The audit opinion $(\mathrm{OPN})$ affects audit delay because it has a significance value of less than 0.05 with a coefficient value of 0.141 . Meanwhile, the variable of company operation complexity (SUBSID), audit tenure (TNRE), and KAP specialization (KAP) do not affect audit delay, because it has a significant value $>0.05$.

\section{Discussion}

Company size reflects the level of operational complexity of a company. Larger companies tend to have shorter audit delays. This is because the company's internal control system is more effective and efficient, making it easier for auditors to audit a company. The accuracy of submitting the financial statements to the public is one of the ways large companies maintain their corporate image in the eyes of the public. Larger companies have the potential for a greater source of funds to pay audit fees so that they get better audit services [31]. Companies with a larger size tend to have external pressures such as maintaining the confidence of investors who make the financial statements to be published immediately so that the audit delay period is shorter [29]. Based on research data, the highest total asset value is 31.66 , or the equivalent of IDR 56,421,973,000 with an audit delay period of 76 days. Meanwhile, the lowest total asset value is 24.53 , or the equivalent of IDR 45,208,352,407 with an audit delay period of 86 days. Investors consider the accuracy of submitting the financial statements to the public as good news because the company can mitigate all risks that can hinder the publication of financial statements [26]. This affects investor policy regarding continued investment in companies. The research results strengthen signaling theory and lending credibility theory. Investors will consider it bad news when a company's audit delay is getting longer because there are indications of problems in the company [41]. The results also support the research conducted by [3], [30], [31] which states that company size can negatively affect the audit delay.

The auditor's opinion is one of the signals for investors to determine the condition of the company. Audit opinion that has the potential to provide bad news for the company encourages auditors to resolve findings through negotiations or discussions with the parties involved. Auditors are expected to expand their audit process when they discover or suspect irregularities and require more time. Opinions other than unqualified encourage companies to change auditors and re-negotiate to maintain their image in the eyes of the public [29]. When the company gets a qualified opinion, management tries to postpone the publication of a qualified opinion the financial statements which is bad news for investors and other interested parties [20]. Based on the research data, companies that received an opinion other than unqualified had an average audit delay of 98 days, while the descriptive statistical test results showed that the average number of audit delay days for the entire sample of companies was 81 days. This reflects that companies with opinions other than unqualified have audit delay periods far above the average. Investors consider a delay in the publication of financial statements as bad news because there are indications of problems with the related company. The research results strengthen signaling theory and lending credibility theory. Signaling theory involves two parties, namely internal parties such as managers who have a role as signal givers and external parties such as investors as signal receivers. the audit opinion is one of the signals that will be received by external parties and used to consider the continuation of investment in the company. the audit opinion can increase the credibility of the financial statements because the financial statements have been examined by a credible independent party, namely the auditor. The results also support the research conducted by [2], [3], [32] which states that audit opinion affects audit delay.

The complexity of company operations relates to the company units that are interrelated and work together to achieve company goals. The number of subsidiaries can reflect the complexity of the audit services provided as well as a measure of whether or not the client's transactions are complex [17]. The initial hypothesis argues that companies with high accounting complexity will produce a high level of 
audit risk so that it requires a longer time in the audit process. However, this can be anticipated by careful preparation of the audit plan, thereby reducing the audit time budget. besides, companies with high operating complexity tend to have good internal controls to reduce audit risks that will arise. High operating complexity is associated with large company sizes. Companies with a larger size will maintain the company's image in the eyes of the public, one of which is through the accuracy of the submission of financial statements. The financial statements that are submitted on time will be considered good news for investors. This strengthens the signaling theory which explains the relationship between the signal provided by the company and the signal receiver, namely investors. The signal received can be considered as good news or bad news by investors. The results of the study also strengthen the lending credibility theory which states that audited the financial statements can increase stakeholder confidence in the information presented because the information is a fair representation. Timely submission of financial statements can increase the credibility of the company's financial statements. The results of this study support the research conducted by [1] and [35] which states that the complexity of company operations does not affect audit delay.

The initial hypothesis states that audit delay will be shorter for a longer tenure. Auditors with longer tenure can gather more client-specific knowledge so that they have a better understanding and streamline the audit process. However, every auditor is required to work professionally in providing audit services to be able to complete the audit process on time so that the audit delay is shorter. Auditors must complete the audit process promptly by applicable regulations because regulations have the authority to regulate individual or organizational behavior [1]. In Indonesia, the period for providing audit services by auditors has been regulated by OJK regulation number 13 of 2017 article 16 which states that the auditor's engagement period with the client is a maximum of 3 consecutive years and there is a break of 2 consecutive years before re-engaging with the same client. The three years engagement period is considered insufficient for the auditor to have special knowledge related to the company being audited. Based on research data, there are 4 companies with a tenure of more than three years with an average audit delay period of 86 days and the rest have a tenure of fewer than 3 years with an average audit delay period of 85 days. This shows that there is no significant difference between the average duration of audit delay by auditors with a tenure of more than 3 years and auditors with a tenure of fewer than 3 years. Professional auditors can complete the audit process promptly due to pressure from clients and regulations. The accuracy of completing the audit process will have an impact on the signals the company provides to investors. This strengthens the signaling theory and lending credibility theory which states that investors will consider it good news when the timely submission of financial statements and audited the financial statements can increase the credibility of the information issued by the company's management. The results of this study support studies [1] and [23], but contradict studies [10] and [11].

Industry-specialized auditors tend to take less time to understand the client's financial reporting system and to resolve complex accounting problems than non-specialist auditors [14]. However, industry-specialized accounting firms cannot produce shorter audit delays when the public accountant's tenure with client companies is short. During the audit implementation period, KAP only became the overseeing agency, while the public accountant was the one conducting the audit. [24] explain that with the rotation of auditors, it is not easy for KAP to become experts and gain specialization status in a certain industry. In Indonesia, audit rotation has been regulated by OJK through OJK regulation number 13 of 2017 article 16 which explains that public accountants only have a maximum audit period of 3 consecutive years and there is a break of 2 consecutive years before re-engaging with the same client. Based on research data, it shows that the KAPs with the highest number of clients in the trade, service, and investment sectors during the 2013-2018 period were KAP Purwantono, Sungkoro, Surja (PSS), and KAP Amir Abadi Jusuf, Aryanto, Mawar (AAJ). The average number of days required by KAP PSS for the audit process is 81 days, while KAP AAJ is 82 days. Based on the results of the descriptive statistical test, it shows that the average number of audit delay days for the entire sample of companies is 81 days, which means that there is no difference in the period for the audit process conducted by specialists and non-specialist accounting firms. Industry specialization does not affect professional auditors because the regulations have regulated the time frame for submitting audited the financial statements and there is also pressure from the client to immediately complete the audit process. The accuracy of the submission of financial statements to the public is considered good news by investors and is useful for maintaining the company's good image. This strengthens the signaling theory and lending credibility theory which states that financial statements audited by professional public accountants can increase the company's credibility. The results of this study support studies [17] and [24], but contradict studies [11] and [14]. 


\section{CONCLUSION}

Based on the discussion, it can be concluded that company size can negatively affect the audit delay. This is because larger companies tend to have a more effective and efficient company internal control system that makes it easier for auditors to audit a company and has external pressure to maintain the company's image in the eyes of the public. Audit opinion affects audit delay. This is because audit opinions, which have the potential to provide bad news for the company, encourage auditors to resolve findings through negotiations or discussions with the parties involved. Auditors are expected to expand their audit process when they discover or suspect irregularities and require more time. The complexity of the company's operations does not affect audit delay. This shows that the level of complexity of the company's operations does not indicate audit risk which can make the audit delay period longer. Companies with high operating complexity tend to have good internal controls to reduce audit risk that will arise. Audit tenure does not affect audit delay. This reflects that the audit tenure cannot project the audit delay period. Auditors must complete the audit process promptly following applicable regulations because regulations have the authority to regulate individual or organizational behavior. KAP specialization does not affect audit delay. This is because industry specialization can not produce shorter audit delays when the public accountant's tenure with client companies is short. During the audit period, the KAP only became the overseeing agency, while the public accountant was the one conducting the audit.

The implication of this research is to provide knowledge for users of financial reports that the delay in submitting financial reports is due to several factors such as company size and audit opinion. This can be used by users of financial statements to review the company's operational effectiveness or consider whether to continue investing in the company or not. The implications from the company side are related to the disclosure of information and the accuracy of the submission of financial reports. This can maintain the company's good image and going concern.

This study has several limitations, namely the first sample used only in companies in the trade, service, and investment sectors. Second, this study only uses the total subsidiary companies for the variable of the complexity of the company's operations. Third, this study only tested 5 independent variables to see the effect on audit delay. Fourth, this study only uses the 2013-2018 sample because there are changes in PSAK 1 for material definitions are adopted from the amendment to IAS 1 Presentation of Financial Statements which took effect in 2019. Further research is suggested to expand the company sector to be tested, increase the diversification of product lines and markets for the complexity of the company's operations, and consider the variables of profitability and leverage as independent variables.

\section{REFERENCES}

[1] Abdillah, M. R., \& Mardijuwono, A. W. (2019). The Effect Of Company Characteristics And Auditor Characteristics To Audit Report Lag. Asian Journal of Accounting Research, 4(1), 129-144. https://doi.org/10.1108/AJAR-052019-0042.

[2] Apadore, K., \& Utara, U. (2020). Board Characteristic and Audit Report Lag. International Journal of Management (IJM), 11(10), 18461860. https://doi.org/10.34218/IJM.11.10.2020. 172.

[3] Apriayanti, A., \& Santosa, S. (2015). Pengaruh Atribut Perusahaan dan Faktor Audit Terhadap Keterlambatan Audit pada Perusahaan yang Terdaftar di Bursa Efek Malaysia. Jurnal Akuntansi Dan Keuangan, 16(2), 7487. https://doi.org/10.9744/jak.16.2.74-87.

[4] BEI. (2014). Pengumuman Penyampaian Laporan Keuangan Auditan yang Berakhir Per 31 Desember 2013. Jakarta.

[5] BEI. (2015). Pengumuman Penyampaian Laporan Keuangan Auditan yang Berakhir Per 31 Desember 2014. Jakarta.

[6] BEI. (2016). Pengumuman Penyampaian Laporan Keuangan Auditan yang Berakhir Per 31 Desember 2015. Jakarta.

[7] BEI. (2017). Pengumuman Penyampaian Laporan Keuangan Auditan yang Berakhir Per 31 Desember 2016. Jakarta.

[8] BEI. (2018). Pengumuman Penyampaian Laporan Keuangan Auditan yang Berakhir Per 31 Desember 2017. Jakarta.

[9] BEI. (2019). Pengumuman Penyampaian Laporan Keuangan Auditan yang Berakhir Per 31 Desember 2018. Jakarta.

[10] Bryan, D. B., \& Mason, T. W. (2020). Earnings volatility and audit report lag. Advances in Accounting, 51, 100496. https://doi.org/10. 1016/j.adiac.2020.100496.

[11] Dao, M. (2014). Audit Tenure, Auditor Specialization And Audit Report Lag. Managerial Auditing Journal, 29(6), 490-512. https://doi. org/10.1108/MAJ-07-2013-0906.

[12] Durand, G. (2019). The determinants of audit report lag: a meta-analysis. Managerial Auditing Journal, 34(1), 44-75. https://doi.org/10.1108/ MAJ-06-2017-1572. 
[13] Dyer, J. C., Mchugh, A. J., \& Iv, J. C. D. (1975). The Timeliness of the Australian Annual Report Times. Journal of Accounting Research, 13(2), 204-219.

[14] Evans, R. J. (2017). Audit Quality and Audit Report Lag: Case of Indonesian Listed Companies. Asian Review of Accounting Article Information, 25(2).

[15] Ferri, M. G., \& Jones, W. H. (1979). Determinants of Financial Structure: A New Methodological Approach. The Journal of Finance, 34(3), 631. https://doi.org/10.2307/2327431

[16] Fitriany, F., Utama, S., Martani, D., \& Rosietta, H. (2016). Pengaruh Tenure, Rotasi dan Spesialisasi Kantor Akuntan Publik (KAP) Terhadap Kualitas Audit: Perbandingan Sebelum dan Sesudah Regulasi Rotasi KAP di Indonesia. Jurnal Akuntansi dan Keuangan, 17(1), 12-27. https://doi.org/10.9744/jak.17. 1.12-27.

[17] Habib, A., Bhuiyan, U., Jiaying, H., \& Miah, M. S. (2018). Determinants of Audit Report Lag: A Meta - Analysis. (May), 1-25. https://doi.org/ 10.1111/ijau.12136.

[18] Habib, A., \& Uddin, B. (2011). Journal of International Accounting, Auditing and Taxation Audit Firm Industry Specialization and the Audit Report Lag. Journal of International Accounting, Auditing and Taxation, 20(1), 3244. https://doi.org/10.1016/j.intaccaudtax.2010. 12.004 .

[19] Hammes, D. D., De Mattos, L. K., \& Flach, L. (2020). Audit report lag determinants: A panel data regression model with all companies listed on the Dow Jones Stock Index. International Journal of Business Excellence, 21(1), 139-152. https://doi.org/10.1504/IJBEX.2020. 106954.

[20] Handoyo, S., \& Maulana, E. D. (2019). Determinants of Audit Report Lag of Financial Statements in Banking Sector. Jurnal Manajemen, Strategi Bisnis dan Kewirausahaan, 13(2), 142-152.

[21] Hassan, Y. M. (2016). Determinants of audit report lag: evidence from Palestine. Journal of Accounting in Emerging Economies, 6(1), 1332. https://doi.org/10.1108/jaee-05-2013-0024.

[22] Hayes, R., Wallage, P., Dassen, R., \& Schilder, A. (2005). Principles of Auditing: An Introduction to International Standards on Auditing (Second). England: McGraw-Hill.

[23] Kaaroud, M. A., \& Ariffin, N. M. (2020). The Extent of Audit Report Lag and Governance Mechanisms in Malaysia. Journal of Islamic Accounting and Business Research, 11(1), 70-89. https://doi.org/10.1108/JABR-05-2017-0069.

[24] Karami, G., Karimiyan, T., \& Salati, S. (2017). Auditor Tenure, Auditor Industry Expertise, and Audit Report Lag: Evidences of Iran.
Iranian Journal of Management Studies, 10(3), 641-666. https://doi.org/10.22059/ijms.2017. 219348.672346

[25] Khoufi, N., \& Khoufi, W. (2018). An Empirical Examination of the Determinants of Audit Report Delay In France. Managerial Auditing Journal. https://doi.org/10.1108/MAJ-02-20171518

[26] Kusumah, R. W. R., \& Manurung, D. (2017). Pentingkah Good Corporate Governance bagi Audit Report Lag? Jurnal Akuntansi Multiparadigma, 8(204), 137-148. https://doi.org/10. 18202/jamal.2017.04.7047

[27] Lawrence, J., \& Bryan, B. (1998). Characteristics Associated With Audit Delay in the Monitoring of Low Income Housing Projects. Journal of Public Budgeting, Accounting \& Financial Management, 34(1), 1-5.

[28] Lee, H., Mande, V., \& Son, M. (2009). Do Lengthy Auditor Tenure and the Provision of Non-Audit Services by the External Auditor Reduce Audit Report Lags? International Journal of Auditing, 104, 87-104. https://doi. org/10.1111/j.1099-1123.2008.00406.x

[29] Lee, H. Y., \& Jahng, G. J. (2008). Determinants of Audit Report Lag: Evidence from Korea - An Examination of Auditor-Related Factors. Journal of Applied Business Research, 24(2), 27-44. https://doi.org/10.19030/jabr.v24i2.1352

[30] Modugu, P. K. (2012). Determinants of Audit Delay in Nigerian Companies : Empirical Evidence. Research Journal of Finance and Accounting, 3(6), 46-55.

[31] Natonis, S. A., \& Tjahjadi, B. (2019). Determinant of Audit Report Lag Among Mining Companies in Indonesia. Jurnal Organisasi dan Manajemen, 15(1), 68. https://doi.org/ 10.33830/jom.v15i1.927.2019

[32] Ocak, M., \& Özden, E. A. (2018). Signing auditor-specific characteristics and audit report lag: A research from Turkey. Journal of Applied Business Research, 34(2), 277-294. https://doi.org/10.19030/jabr.v34i2.10129

[33] OJK. Laporan Lembaga Penyimpanan dan Penyelesaian, Peraturan Otoritas Jasa Keuangan No.44/POJK.04/2016 § (2016).

[34] Putri, F. K. (2018). Menariknya Industri Pasar Modal Indonesia. Retrieved March 15, 2021, from www.kampungpasarmodal.com website: https://kampungpasarmodal.com/article/detail /13/menariknya-industri-pasar-modal-indonesia

[35] Salleh, Z., Baatwah, S. R., \& Ahmad, N. (2017). Audit Committee Financial Expertise and Audit Report Lag: Malaysia Further Insight. Asian Journal of Accounting and Governance, 8, 137-150. https://doi.org/10.17576/ajag-201708-12 
[36] Spence, M. (1972). Job Market Signalling. The Quarterly Journal of Economics, 87(3), 355374.

[37] Stewart, E. G., Cairney, T. D., Stewart, E. G., \& Cairney, T. D. (2019). Audit Report Lag and Client Industry Homogeneity. Managerial Auditing Journal, 34(1). https://doi.org/10. 1108/MAJ-07-2018-1931.

[38] Sultana, N., Singh, H., \& Van der Zahn, J. L. W. M. (2015). Audit Committee Characteristics and Audit Report Lag. International Journal of Auditing, 19(2), 72-87. https://doi. org/10.1111/ijau.12033.

[39] Syachrudin, D., \& Nurlis. (2018). Influence of Company Size, Audit Opinion, Profitability,
Solvency, And Size of Public Accountant Offices to Delay Audit on Property Sector Manufacturing Companies Listed in Indonesia Stock Exchange. International Journal of Scientific \& Technology Research, 7(10).

[40] Tuanakkotta, T. M. (2017). Audit Kontemporer (erma sri Suharsi, Ed.). Jakarta: Salemba Empat.

[41] Wan-Hussin, W. N., \& Bamahros, H. M. (2013). Do investment in and the sourcing arrangement of the internal audit function affect audit delay? Journal of Contemporary Accounting and Economics, 9(1), 19-32. https://doi.org/10.1016/j.jcae.2012.08.001 